\title{
A Preliminary Evaluation of Black and Navy Bean Productivity in Virginia
}

\author{
Tyler Smith ${ }^{1, \dagger}$, Anwar Hamama ${ }^{1}$, Zaid Abraha-Eyob ${ }^{1}$ \& Harbans Bhardwaj ${ }^{1}$ \\ ${ }^{1}$ Agricultural Research Station, Virginia State University, Petersburg, Virginia, USA \\ Correspondence: Harbans L. Bhardwaj, Agricultural Research Station, Virginia State University, Petersburg, \\ Virginia 23806, USA. Tel: 1-804-524-6723. Fax: 1-804-524-5950. E-mail: hbhardwaj@vsu.edu
}

Received: June 15, 2018

doi:10.5539/jas.v10n10p98

Accepted: July 18, $2018 \quad$ Online Published: September 15, 2018

URL: https://doi.org/10.5539/jas.v10n10p98

The research is financed by US Department of Agriculture-Evans-Allen Program.

${ }^{\dagger}$ This study was conducted as a student training project for the first author (TS). Contribution of Virginia State University, Agricultural Research Station. Use of any trade names or vendors does not imply approval to the exclusion of other products or vendors that may also be suitable.

\begin{abstract}
Black and navy beans (Phaseolus vulgaris L.) are economically important crops for US Agriculture and provide nutritious food for humans. These crops are predominantly grown in Colorado, Idaho, Michigan, Nebraska, North Dakota, and Washington states. We are interested in introducing these crops in Virginia as alternative summer crops. Four cultivars each of black (Eclipse, T-39, Zenith and Zorro) and navy bean (Alapena, Avalanche, Norstar, and Vista) were grown in the field at Randolph Farm of Virginia State University in Ettrick, Virginia during 2016. We planted these twice (May 26 and June 30) by using two inter-row spacings (37.5 and $75 \mathrm{~cm})$. Results indicated that yields of black bean $(1691 \mathrm{~kg} / \mathrm{ha})$ didn't differ significantly from that of navy bean $(1402 \mathrm{~kg} / \mathrm{ha})$. Effects of cultivars and row spacings were not significant. Seed yield for May planting date (883 $\mathrm{kg} / \mathrm{ha}$ ) was significantly lower than that for June planting $(2210 \mathrm{~kg} / \mathrm{ha})$. Concentrations of protein, $\mathrm{P}, \mathrm{K}, \mathrm{Ca}, \mathrm{Mg}$, $\mathrm{S}, \mathrm{Al}, \mathrm{B}, \mathrm{Cu}, \mathrm{Fe}, \mathrm{Mn}$, fructose, glucose, sucrose, raffinose, stachyose, verbascose, total sugar, insoluble dietary fiber, and total dietary fiber in black and navy bean seeds were not different. Black bean had significantly higher soluble dietary fiber concentration (4.46\%) as compared to navy bean (3.68\%). Nutritional quality traits of black and navy bean seed produced in Virginia compared well with values in the literature. Based on desirable seed yield levels and nutritional quality, it was concluded that black and navy bean are potential new/alternate crops for Virginia and adjoining areas in the mid-Atlantic region of United States of America.
\end{abstract}

Keywords: Phaseolus vulgaris, minerals, protein, dietary fiber, crop diversification

\section{Introduction}

Need for crop diversification is recognized as one of the important factors for production of adequate and nutritious food for the growing human population on a world-wide basis. This is especially true of US agriculture which depends upon a limited number of crops. New crops have been important to American agriculture as most crops currently grown in the United States were imports from different parts of the world. The importance of crop diversification in the success of Australian and Canadian agriculture is well documented. Fletcher (2002) indicated that at least $67 \%$ of the increased value of crop production in Australia over the period 1950-1992 was derived from new crops. Blade and Slinkard (2002) cited successful cultivation of many new crops in Canada such as canola, chickpea, field pea, lentil, mustard, canary seed, sunflower, and many spice crops. Sustainable Agriculture Network (SARE, 2004) indicated that we need to diversify crops to enhance profits, to soften impacts of environmental resources, to spread farmer's economic risk, to exploit markets, to create new industries, and to aid the domestic economy. Alternative crops research has been going on at Virginia State University since 1993 (Bhardwaj et al., 1996).

Common bean (Phaseolus vulgaris $\mathrm{L}$.; $2 \mathrm{n}=2 \mathrm{x}=22$ ), a collective term that includes dry bean, is an important economic crop in the US. During 2008, approximately 1.7 million acres of dry and snap beans were planted in 
the United States. Production of dry beans is primarily located in North Dakota, Michigan, Nebraska, and Colorado (90\% of production). Snap beans are grown for the fresh and processing markets on 300,000 acres, primarily in Oregon, Wisconsin, and New York. Collectively, the value of common bean production at the farm gate in 2008 was $\$ 1.5$ billion whereas the value of production during 2014 and 2015 was approximately 980 million and 866 million dollars, respectively indicating a decline in value of production. During most years, dry bean value exceeds the value of all other vegetable legumes combined (chickpea, lentil, pea, and peanut). US breeders focus on five dry bean classes (pinto, navy, black, Great Northern, kidney) and snap beans for the fresh and processing markets. Each market class is defined by a specific seed size, color, and pattern, traits controlled by many genes (McClean, 2002). ERS (2017) has listed the leading varieties of dry edible beans as: Pinto 42\%; Navy 17\%; Black 11\%; Great Northern 5\%; and Garbanzo (large chickpeas) 5\%.

Commercial production of dry beans is concentrated in Colorado, Idaho, Michigan, Nebraska, North Dakota, and Washington states as evidenced the following Figure 1 (BeanCAP, 2009). This figure indicates lack of any tangible production in the eastern United States. Even though dry beans (Phaseolus vulgaris L.) are not a traditional component of the existing cropping system they have considerable potential as alternative crops in Virginia and adjoining states. These crops have excellent positive effects on human health and consumers are incorporating increasing amounts in their diets.

\section{U.S. Bean Producing States}

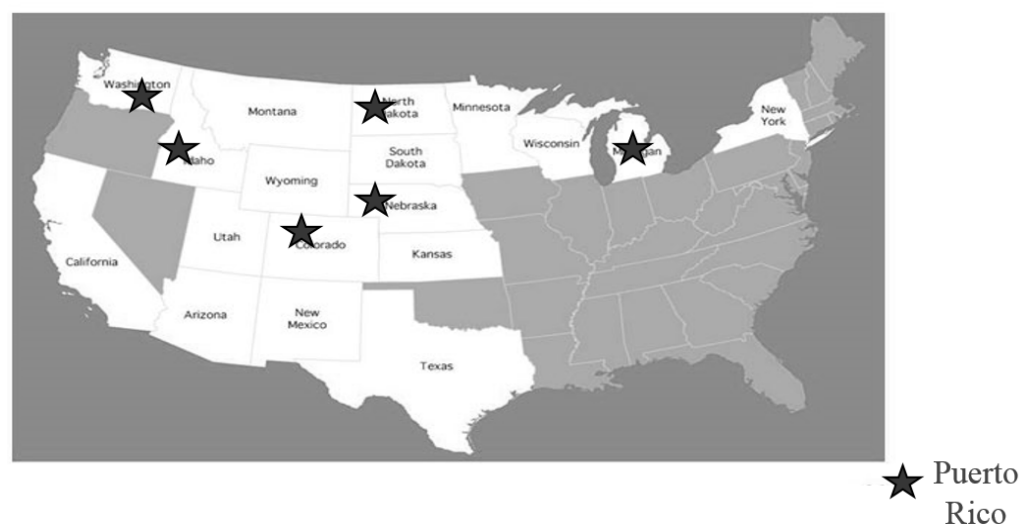

Figure 1. Concentrated areas of commercial production of dry beans

Our objectives were to characterize nutritional quality of black and navy bean in Virginia, compare their nutritional quality to that available in literature, and to make a judgement about the potential of these food legume crops in Virginia and adjoining areas.

\section{Materials and Methods}

\subsection{Plant Material and Production}

Four cultivars each of black (Eclipse, T-39, Zenith and Zorro) and navy (Alapena, Avalanche, Norstar, and Vista) bean were grown in the field (Abel sandy loam-Fine Loamy mixed thermic Aquatic Hapridult soil) at Randolph Farm of Virginia State University in Ettrick, Virginia during 2016. We used two planting dates (May 26 and June 30 ) and two row spacings $(37.5$ and $75 \mathrm{~cm}$ ) using a RCBD with four replications. The experiment was designed as a split-plot with planting dates as main plots, cultivars as subplots, and row spacings as sub-subplots. Each plot consisted of four rows spaced either 0.375 or $0.75 \mathrm{~m}$ apart with $1.5 \mathrm{~m}$ distance between plots. Each experiment consisted of four replications per planting date. The rows were $3.6 \mathrm{~m}$ long. About 100 seeds were planted in each row with a tractor-driven research planter. The seed depth was 2 to $3 \mathrm{~cm}$. These plots received 30 $\mathrm{kg} / \mathrm{ha}$ each of N, P, and K. Experimental area received a preplant incorporated treatment of Trifluralin herbicide at the rate of 1 liter/ha. The plots were manually weeded once. All plots were harvested upon maturity in fall season of 2016.

\subsection{Analysis of Seed Composition}

We used raw mature seeds of each of the four cultivars of black (Eclipse, T-39, Zenith, and Zorro) and navy bean (Alapena, Avalanche, Norstar, and Vista) grown for these studies. Seed from two replications were used for nutritional quality analyses. Mineral concentrations, including nitrogen $(\mathrm{N})$, in seed were determined according 
to AOAC methods (AOAC, 2016) by Waypoint Analytical Laboratory (Richmond, Virginia, USA). Total protein concentration was calculated by multiplying $\mathrm{N}$ content with protein factor 6.25 .

Sugars were extracted from ground sample $(1 \mathrm{~g})$ and analyzed by HPLC following methods optimized by Johansen et al. (1996). Sugars in the extracts were identified by comparing their retention times with standard sugars. For quantification, trehalose was used as internal standard and the sugar concentration was expressed as g per $100 \mathrm{~g}$ meal (Bhardwaj \& Hamama, 2016).

Dietary fiber concentrations (Insoluble, soluble, and total dietary fiber) were determined using AOAC 991.43 method using the ANKOM TDF Dietary Fiber Analyzer in the Common Laboratory of Virginia State University. This method uses Filter Bag Technology to determine the concentrations IDF (insoluble fiber), SDF (soluble fiber) and TDF (total fiber) within a given sample using the weight of the recovered IDF and SDF residue corrected for ash and protein content.

All data were analyzed using version 9.1 of SAS (SAS Institute, Inc., 2014) using ANOVA with 5 percent level of significance. Seed composition traits of black and navy bean produced in this study were compared to those in the literature.

\section{Results and Discussion}

Effects of cultivars and row spacings on seed yield were generally non-significant (Table 1). Late planting (June 30) resulted in significantly higher seed yield as compared to early planting (May 26), 2210 and $883 \mathrm{~kg} / \mathrm{ha}$, respectively. Seed yields of both black and navy bean were statistically similar (1691 and $1402 \mathrm{~kg} / \mathrm{ha}$, respectively) even though seed yield of black bean (averaged over four cultivars) was approximately $21 \%$ higher than that of navy bean. In our opinion, these differences are expected to be more pronounced after inclusion of a wider array of cultivars of both types in future studies. Based on these results, we conclude that seed yields of both black and navy beans produced in Virginia are acceptable based on average yields of other summer crops such as double-crop soybean. Higher seed yield from late planting indicates that black and navy bean might need higher temperature for successful growth and production. These results indicate that production of black and navy bean in rotation with winter wheat (Generally planted in October-November and harvested in late June-early July) may be possible.

Table 1. Seed yields from bean field experiments during 2016 at Petersburg, Virginia

\begin{tabular}{lll}
\hline Type & Cultivar & Seed yield (kg/ha) \\
\hline Black bean & Eclipse & $1780.4 \mathrm{a}$ \\
& T-39 & $1848.8 \mathrm{a}$ \\
& Zenith & $1224.3 \mathrm{a}$ \\
& Zorro & $1911.4 \mathrm{a}$ \\
\hline Navy bean & Alapena & $1467.0 \mathrm{a}$ \\
& Avalanche & $1198.7 \mathrm{a}$ \\
& Norstar & $1322.1 \mathrm{a}$ \\
\hline Row spacing & Vista & $1620.5 \mathrm{a}$ \\
& 15 -inch & $1697.7 \mathrm{a}$ \\
\hline Planting date & 30 -inch & $1395.6 \mathrm{a}$ \\
\hline Bean type & May 26, 2016 & $883.3 \mathrm{~b}$ \\
& June 30,2016 & $2210.0 \mathrm{a}$ \\
\hline
\end{tabular}

Note. * Means followed by similar letters were not different according to Duncan’s Multiple Range Test ( $5 \%$ level).

Differences among four black bean cultivars for nutritional quality traits (Table 2) were non-significant except when Zorro had significantly higher Ca concentration over Zenith. Differences among four navy bean cultivars for nutritional quality traits (Table 2) were non-significant except when Avalanche had significantly higher concentration of $\mathrm{Cu}, \mathrm{S}, \mathrm{P}, \mathrm{Zn}, \mathrm{Ca}$, Sucrose, Raffinose total sugar over different cultivars. 
Table 2. Comparison of nutritional quality traits of Virginia-grown black and navy bean with literature values

\begin{tabular}{|c|c|c|c|c|c|c|c|}
\hline Trait & Black bean $^{1}$ & Navy bean ${ }^{2}$ & Pinheiro $^{3}$ & Duenas $^{4}$ & Pedrosa $^{5}$ & $\mathrm{USDAa}^{6}$ & $\mathrm{USDAb}^{7}$ \\
\hline Protein (\%) & $25.0 \mathrm{a}^{*}$ & $25.1 \mathrm{a}^{*}$ & $21-30$ & 17.8 & $24.9-26.6$ & 21.6 & 22.3 \\
\hline $\mathrm{P}(\%)$ & $0.59 \mathrm{a}$ & $0.61 \mathrm{a}$ & $0.50-0.80$ & & & 0.35 & 0.41 \\
\hline $\mathrm{K}(\%)$ & $1.59 \mathrm{a}$ & $1.55 \mathrm{a}$ & $1.24-2.12$ & & & 1.48 & 1.18 \\
\hline $\mathrm{Ca}(\%)$ & $0.18 \mathrm{a}$ & $0.18 \mathrm{a}$ & $0.07-0.29$ & & $0.04-0.16$ & 0.12 & 0.15 \\
\hline $\operatorname{Mg}(\%)$ & $0.21 \mathrm{a}$ & $0.22 \mathrm{a}$ & $0.13-0.25$ & & $0.10-0.15$ & 0.17 & 0.17 \\
\hline S (\%) & $0.24 \mathrm{a}$ & $0.24 \mathrm{a}$ & & & & & \\
\hline $\mathrm{Al}(\mathrm{ppm})$ & $11.4 \mathrm{a}$ & $12.7 \mathrm{a}$ & & & & & \\
\hline $\mathrm{B}(\mathrm{ppm})$ & $10.1 \mathrm{a}$ & $10.1 \mathrm{a}$ & & & & & \\
\hline $\mathrm{Cu}(\mathrm{ppm})$ & $12.4 \mathrm{a}$ & $12.4 \mathrm{a}$ & $4.7-13.5$ & & & & \\
\hline $\mathrm{Fe}(\mathrm{ppm})$ & $44.4 \mathrm{a}$ & $48.4 \mathrm{a}$ & $32-88$ & & $52-60$ & 50.2 & 54.9 \\
\hline $\mathrm{Mn}(\mathrm{ppm})$ & $14.9 \mathrm{a}$ & $15.4 \mathrm{a}$ & $8-20$ & & & & \\
\hline $\mathrm{Zn}(\mathrm{ppm})$ & $31.9 \mathrm{a}$ & $30.2 \mathrm{a}$ & $11.5-45.3$ & & $21.6-24.0$ & 36.5 & 36.50 \\
\hline Fructose $^{8}$ & $0.84 \mathrm{a}$ & $0.86 \mathrm{a}$ & & & & & \\
\hline Glucose $^{8}$ & $0.44 \mathrm{a}$ & $0.55 \mathrm{a}$ & & & & & \\
\hline Sucrose $^{8}$ & $2.29 \mathrm{a}$ & $2.44 \mathrm{a}$ & & & $3.1-3.5$ & & \\
\hline Raffinose $^{8}$ & $0.39 \mathrm{a}$ & $0.48 \mathrm{a}$ & & & $0.12-0.13$ & & \\
\hline Stachyose $^{8}$ & $1.80 \mathrm{~b}$ & $2.31 \mathrm{a}$ & & & $2.72-2.79$ & & \\
\hline Verbascose $^{8}$ & $0.00 \mathrm{a}$ & $0.01 \mathrm{a}$ & & & & & \\
\hline Total sugars ${ }^{8}$ & $5.75 \mathrm{~b}$ & $6.64 \mathrm{a}$ & & & & 2.12 & 3.88 \\
\hline IDF $^{9}$ & $15.6 \mathrm{a}$ & $14.4 \mathrm{a}$ & & 21.4 & & & \\
\hline $\mathrm{SDF}^{9}$ & $4.46 \mathrm{a}$ & $3.68 \mathrm{~b}$ & & 5.8 & & & \\
\hline $\mathrm{TDF}^{9}$ & $20.0 \mathrm{a}$ & $18.3 \mathrm{a}$ & & 27.2 & $32.3-32.7$ & 15.5 & 15.3 \\
\hline
\end{tabular}

Note. ${ }^{1}$ Means based on four cultivars (Eclipse, T-39, Zenith, and Zorro); ${ }^{2}$ Means based on four cultivars (Alapena, Avalanche, Norstar, and Vista); ${ }^{3}$ Pinheiro et al. (2010); ${ }^{4}$ Duenas et al. (2016); ${ }^{5}$ Pedrosa et al. (2015); ${ }^{6}$ USDA (2018a); ${ }^{7}$ USDA (2018b); ${ }^{8} \mathrm{~g} / 100 \mathrm{~g}$ meal; ${ }^{9}$ Insoluble, soluble, and total dietary fiber, respectively (\%);

* Means followed by similar letters were not different according to Duncan's Multiple Range Test (5\% level).

As groups, differences between black and navy bean for nutritional quality traits (Table 2) were not significant except for concentrations of total sugar (5.75 vs. 6.64\%) and soluble dietary fiber (4.46 vs. 3.68\%). Observational comparisons of nutritional quality of Virginia-grown black and navy bean with literature values and the standard reference values maintained by Agricultural Research Service, USDA (USDA, 2018a, USDA, 2018b) revealed that, in general, nutritional quality of black and navy bean produced in Virginia is not different than values reported in the literature.

Results of this preliminary study indicated that both black and navy bean could be developed as alternate food crops for farmers in Virginia and adjoining areas. These results, however, are from only one year's data and should be repeated. Additionally, the results implied that a possibility of producing black and navy bean in rotation with winter wheat exists. This observation, if confirmed by further studies, could result in significant enhancement of farm economies in Virginia and adjoining areas. Dry bean (Phaseolus vulgaris L.) are consumed by humans more than any other legume crop. The health benefits from eating beans are numerous and include reducing the cholesterol and sugar levels in blood which prevent or alleviate certain types of cancer, Type 2 diabetes, and cardiovascular diseases. Diets rich in zinc and iron, two micronutrients abundant in dry bean, can delay the onset of AIDS and as such, HIV positive patients are encouraged to include beans in their diets. Recently, research has shown that beans significantly reduce the onset of breast cancer, colon cancer, and biomarkers for heart disease risk (BeanCap, 2009). Current study, demonstrates that production of black and navy bean can be expanded to Virginia and adjoining areas not only to help farm economy but also to provide a source of healthy food for human consumption.

\section{Acknowledgements}

Authors are thankful to Virginia State University and US Department of Agriculture (NIFA/Evans-Allen Program) for supporting this research with financial and physical resources. Authors also thank Dr. John Kelly (Michigan State University) and Dr. Juan Osorno (North Dakota State University) for providing seed for this study.

\section{References}

AOAC (Association of Official Analytical Chemists). (2016). Official Methods of Analysis (20th ed.). AOAC, 
Arlington, VA. Retrieved from http://www.aoac.org/aoac_prod_imis/AOAC/AOAC_Member/PUBSCF/ OMACF/OMAP_M.aspx

BeanCAP. (2009). Common Bean Coordinated Agricultural Project. BeanCAP, Michigan State University, East Lansing, MI. Retrieved from http://www.beancap.org

Bhardwaj, H. L., Hankins, A., Mebrahtu, T., Mullins, J., Rangappa, M., Abaye, O., \& Welbaum, G. E. (1996). Alternative crops research in Virginia. In J. Janick (Ed.), Progress in new crops (pp. 87-96). ASHS, Alexandria, VA. Retrieved from https://hort.purdue.edu/newcrop/proceedings1996/V3-087.html

Bhardwaj, H. L., \& Hamama, A. A. (2016). Cultivar, Planting Date, and Row Spacing Effects on Mungbean Seed Composition. Journal of Agricultural Science, 8(10), 26-32. https://doi.org/10.5539/jas.v8n10p26

Blade, S. F., \& Slinkard, A. E. (2002). New crop development: The Canadian experience. In J. Janick \& A. Whipkey (Eds.), Trends in New Crops and New Uses (pp. 62-75). ASHS Press, Alexandria, VA.

Duenas, M., Sarmento, T., Aguilera, Y., Benitez, V., Molla, E., Esteban, R. M., \& Martin-Cabrejas, M. A. (2016). Impact of cooking and germination on phenolic composition and dietary fibre fractions in dark beans (Phaseolus vulgaris L.) and lentils (Lens culinaris L.). Food Science and Technology, 66, 72-78. https://doi.org/10.1016/j.lwt.2015.10.025

ERS. (2017). Dry Beans. Retrieved from https://www.ers.usda.gov/topics/crops/vegetables-pulses/dry-beans. aspx\#drybean

Fletcher, R. J. (2002). International new crop development incentives, barriers, processes, and progress: An Australian experience. In J. Janick \& A. Whipkey (Eds.), Trends in New Crops and New Uses (pp. 40-54). ASHS Press, Alexandria, VA.

Johansen, H. N., Gilts, V., \& Knudsen, K. E. N. (1996). Influence of Extraction Solvent and Temperature on the Quantitative Determination of Oligosaccharides from Plant Materials by High-Performance Liquid Chromatography. J. Agric. Food Chem., 44, 1470-1474. https://doi.org/10.1021/jf950482b

McClean, P. E., Lee, R. K., Otto, C., Gepts, P., \& Bassett, M. J. (2002). Molecular and phenotypic mapping of genes controlling seed coat pattern and color in common bean (Phaseolus vulgaris L.). J. Heredity, 93, 148-152. https://doi.org/10.1093/jhered/93.2.148

Pedrosa, M. M., Cuadrado, C., Burbano, C., Muzquiz, M., Cabellos, B., Olmedilla-Alonso, B., \& Asensio-Vegas, C. (2015). Effects of industrial canning on the proximate composition, bioactive compounds contents and nutritional profile of two Spanish common dry beans (Phaseolus vulgaris L.). Food Chemistry, 166, 68-75. https://doi.org/10.1016/j.foodchem.2014.05.158

Pinheiro, C., Baeta, J. P., Pereira, A. M., Domingues, H., \& Ricardo, C. P. (2010). Diversity of seed mineral composition of Phaseolus vulgaris L. germplasm. Journal of Food Composition and Analysis, 23, 319-325. https://doi.org/10.1016/j.jfca.2010.01.005

SARE (Sustainable Agriculture Research \& Education). (2004). Diversifying Cropping Systems. U.S. Department of Agriculture, University of Maryland, College Park, MD. Retrieved from https://www.sare. org/Learning-Center/Bulletins/Diversifying-Cropping-Systems

SAS Institute, Inc. (2014). SAS for Windows (Version 9.4). SAS Institute, Inc., Cary, N.C. Retrieved from http://www.sas.com/en_us/software/sas9.html

USDA (U.S. Department of Agriculture). (2018a). USDA National Nutrient Database for Standard Reference, Basic Report 16014. Nutrient Data Laboratory Home Page, U.S. Department of Agriculture, Agricultural Research Service. Retrieved from http://www.ars.usda.gov/nutrientdata

USDA (U.S. Department of Agriculture). (2018b). USDA National Nutrient Database for Standard Reference, Basic Report 16037. Nutrient Data Laboratory Home Page, U.S. Department of Agriculture, Agricultural Research Service. Retrieved from http://www.ars.usda.gov/nutrientdata

\section{Copyrights}

Copyright for this article is retained by the author(s), with first publication rights granted to the journal.

This is an open-access article distributed under the terms and conditions of the Creative Commons Attribution license (http://creativecommons.org/licenses/by/4.0/). 